\title{
Resilience to audiogenic seizures is associated with p-ERK1/2 dephosphorylation in the subiculum of Fmr1 knockout mice
}

\section{Giulia Curia ${ }^{1}$, Fabio Gualtieri ${ }^{1,2}$, Regina Bartolomeo ${ }^{1}$, Riccardo Vezzali ${ }^{1}$ and Giuseppe Biagini ${ }^{1 *}$}

'Laboratory of Experimental Epileptology, Department of Biomedical, Metabolic, and Neural Sciences, University of Modena and Reggio Emilia, Modena, Italy

2 Department of Neurology and Neurosurgery, Montreal Neurological Institute, McGill University, Montreal, OC, Canada

\section{Edited by:}

Roberto Di Maio, University

of Pittsburgh, USA

Reviewed by:

Corette J. Wierenga, Utrecht

University, Netherlands

Pierangelo Cifelli, Ri.MED

Foundation, Italy

\section{*Correspondence:}

Giuseppe Biagini, Laboratorio

di Epilettologia Sperimentale,

Dipartimento di Scienze

Biomediche, Metaboliche e

Neuroscienze, Sezione di

Fisiologia e Neuroscienze, Università

di Modena e Reggio Emilia, Via

Campi 287 - 41125, Modena, Italy.

e-mail:gbiagini@unimore.it
Young, but not adult, fragile $\mathrm{X}$ mental retardation gene ( $F m r 1)$ knockout $(\mathrm{KO})$ mice display audiogenic seizures (AGS) that can be prevented by inhibiting extracellular signal-regulated kinases $1 / 2$ (ERK1/2) phosphorylation. In order to identify the cerebral regions involved in these phenomena, we characterized the response to AGS in Fmr1 KO mice and wild type (WT) controls at postnatal day (P) 45 and P90. To characterize the diverse response to AGS in various cerebral regions, we evaluated the activity markers FosB/ $\Delta$ FosB and phosphorylated ERK1/2 (p-ERK1/2). Wild running (100\% of tested mice) followed by clonic/tonic seizures (30\%) were observed in P45 Fmr1 KO mice, but not in WT mice. In P90 Fmr1 KO mice, wild running was only present in $25 \%$ of tested animals. Basal FosB/ $\triangle$ FosB immunoreactivity was higher $(P<0.01$ vs. WT) in the CA1 and subiculum of P45 Fmr1 KO mice. Following the AGS test, FosB/AFosB expression consistently increased in most of the analyzed regions in both groups at P45, but not at P90. Interestingly, FosB/ $\triangle$ FosB immunoreactivity was significantly higher in P45 Fmr1 KO mice in the medial geniculate body $(P<0.05$ vs. WT) and CA3 $(P<0.01)$. Neurons presenting with immunopositivity to $\mathrm{p}$-ERK1/2 were more abundant in the subiculum of Fmr1 KO mice in control condition ( $P<0.05$ vs. WT, in both age groups). In this region, p-ERK1/2immunopositive cells significantly decreased $(-75 \%, P<0.01)$ in P90 Fmr1 KO mice exposed to the AGS test, but no changes were found in P45 mice or in other brain regions. In both age groups of WT mice, p-ERK1/2-immunopositive cells increased in the subiculum after exposure to the acoustic test. Our findings illustrate that FosB/ $\Delta$ FosB markers are overexpressed in the medial geniculate body and CA3 in Fmr1 KO mice experiencing AGS, and that p-ERK1/2 is markedly decreased in the subiculum of Fmr1 $\mathrm{KO}$ mice resistant to AGS induction. These findings suggest that resilience to AGS is associated with dephosphorylation of p-ERK1/2 in the subiculum of mature Fmr1 KO mice.

Keywords: acoustic stimulus, epilepsy, extracellular signal-regulated kinase (ERK), FosB, Fragile X Syndrome, hippocampus, geniculate body, subiculum

\section{INTRODUCTION}

The Fragile X Syndrome (FXS) is one of the leading causes of mental retardation (Rousseau et al., 1995; Dombrowski et al., 2002). In FXS, CGG triplet expansion in the fragile $X$ mental retardation gene (Fmrl) prevents the synthesis of the fragile $\mathrm{X}$ mental retardation protein (FMRP) (De Rubeis and Bagni, 2010), causing anatomical and functional alterations, such as abnormal dendrite spines morphology and dysfunctions in synaptic plasticity (Zalfa et al., 2006). Individuals affected by FXS suffer from mental retardation, learning disabilities, and attention deficit. They also show behavioral problems including anxiety, autism, hyperactivity, and aggression (Hagerman, 1996). FXS patients may also respond to olfactory, tactile, visual, and auditory stimuli with hyper-reactivity and convulsions (Ferri et al., 1994; Miller et al., 1999; Berry-Kravis et al., 2010). The prevalence of epilepsy in FXS is larger than in the normal population, ranging from 14 to $50 \%$ of FXS patients (Berry-Kravis, 2002).
Epilepsy associated with FXS is generally benign, spontaneously remitting during or immediately after adolescence (Singh et al., 1999). Rolandic epileptiform potentials during hand tapping suggest neurophysiological similarities between FXS and benign childhood epilepsy with centrotemporal spikes (Musumeci et al., 1994). In absence of external stimulation, epileptic condition in FXS patients has been extensively investigated (Musumeci et al., 1988, 1991, 1999; Sabaratnam et al., 2001; Berry-Kravis et al., 2010; Gauthey et al., 2010). Seizures in FXS individuals appear after the age of 2 years with some cases of late onset. They are frequently complex partial seizures, but simple partial seizures, generalized tonic-clonic seizures, febrile convulsions, and status epilepticus have been observed as well. Seizure foci are commonly located in frontal or temporal lobes. Although in most of the epileptic FXS patients seizures are well controlled by antiepileptic drugs (Hagerman and Stafstrom, 2009), sometimes they may be frequent, severe and unresponsive 
to treatments (Sabaratnam et al., 2001; Incorpora et al., 2002). Even when very mild and well controlled pharmacologically, seizures may still be dangerous for FXS patients. Indeed, recently it has been demonstrated that in an animal model of temporal lobe epilepsy (TLE), pilocarpine-treated rats experiencing seizures show an increase in dopamine neuron activity and an increase in amphetamine-stimulated locomotor activity, suggesting that TLE-associated psychosis is probably due to abnormal hippocampal overdrive of dopamine neuron activity (Cifelli and Grace, 2012). In addition, a number of well-known genetic disorders, including FXS, but also tuberous sclerosis complex and Rett Syndrome, shares epilepsy, intellectual disability and autism (Brooks-Kayal, 2011), suggesting a possible link between epilepsy and psychiatric disorders. In recent studies it has been found an increased incidence of seizures in individuals with FXS also diagnosed with autism compared to FXS patients without autism (Garcia-Nonell et al., 2008; Berry-Kravis et al., 2010). In addition, it has been shown that in another form of mental retardation, the Down Syndrome, cognitive deficit is more pronounced in patients presenting epilepsy than in Down Syndrome patients without epilepsy (Eisermann et al., 2003). These observations suggest that early life seizures can result in cellular and molecular changes that could contribute to learning and behavioral disabilities and that, similarly to Down Syndrome, also in FXS, epilepsy may play a crucial role in worsening cognitive functions. As electroencephalographic (EEG) abnormalities have been observed also in non-epileptic FXS patients (Berry-Kravis, 2002), and short non-spreading events not associated with obvious clinical manifestations (subclinical seizures) have been demonstrated in other forms of partial epilepsy (D'Ambrosio et al., 2009), abnormal brain activity can actually be a problem not restricted to the $23 \%$ of FXS population presenting with spontaneous motor seizures. Therefore, a better understanding of epileptic activity in FXS is crucial for improving quality of life of all FXS patients.

Fmr1 knockout (KO) mice provide a suitable animal model for studying FXS because they reproduce the FXS phenotype (The Dutch-Belgian Fragile X Consorthium, 1994). Although they have not been evaluated for epilepsy prospectively by video-EEG, the presence of age-dependent epilepsy was reported in these mice (Musumeci et al., 1999, 2000). Similarly to FXS patients, they are characterized by an anomalous reaction to sensory stimuli (Musumeci et al., 2000) and show audiogenic seizures (AGS), characterized by wild running followed by clonic, tonic-clonic, and/or tonic convulsions in response to loud sounds (Henry, 1967; Musumeci et al., 2000; Chen and Toth, 2001). Recent studies have demonstrated that inhibitors of extracellular signalregulated kinases $1 / 2$ (ERK1/2) phosphorylation prevent AGS induction in Fmr1 KO mice (Osterweil et al., 2010; Michalon et al., 2012; Wang et al., 2012). In order to further investigate the role of phosphorylated ERK1/2 (p-ERK1/2) in AGS in the FXS mouse model, we considered two different age groups of Fmr1 $\mathrm{KO}$ mice and compared them with age-matched wild type (WT) control animals. Both genotypes were exposed to the test for AGS induction at postnatal day (P) 45 or P90. In order to verify the effects of the testing procedure and AGS induction on neuronal networks, we also investigated the expression of the activity markers FosB/ $\triangle$ FosB (Biagini et al., 2005, 2008), the ideal tool available now to investigate network activity in epileptic animals (Chen et al., 1997; Biagini et al., 2005; Madsen et al., 2006) since products of the $f o s B$ gene family are stable and tend to accumulate in repeatedly activated neurons (Chen et al., 1997; Kelz and Nestler, 2000). Instead, c-Fos, another tool being used for many years to track acute changes in neuronal network activity (Chen and Toth, 2001), is extremely short living making c-Fos reliability questionable in cases of recurrent neuronal synchronization. In line with the previous findings in other models of epilepsy (Biagini et al., 2005 , 2008), we found that FosB/ $\Delta$ FosB immunoreactivity was significantly correlated with seizure induction in P45 Fmr1 KO mice, especially in acoustic regions (medial geniculate body) and the hippocampus proper (CA3). Interestingly, p-ERK1/2 was not significantly changed in Fmr1 KO mice experiencing seizures, but it was instead markedly decreased in the subiculum of P90 Fmr1 $\mathrm{KO}$ mice that were resistant to AGS induction. These findings suggest that the disappearance of sensitivity to AGS during development is associated with dephosphorylation of $\mathrm{p}$-ERK $1 / 2$ in the subiculum.

\section{MATERIALS AND METHODS ANIMALS}

Male C57BL/6 WT $(n=22)$ and C57BL/6 Fmr1 KO mice $(n=25)$ were studied at P45 $(n=25)$ or P90 $(n=22)$. Mice were housed at the animal facility of the Montreal Neurological Institute and sacrificed after the testing procedure. All the procedures were approved by the Canadian Council of Animal Care and were in accordance with the European Communities Council Directive 2010/63/EU.

\section{AUDIOGENIC TESTS}

The experimental chamber consisted in a plastic cage $25 \times 25 \times$ $47 \mathrm{~cm}$ in which the doorbell (Electrical bell Heath Zenith, model $172 \mathrm{C}-\mathrm{A}$ ) was mounted on the cage roof. Mice were taken from their housing room one by one, transferred into the experimental chamber and allowed to explore the novel environment (basal noise $\sim 65 \mathrm{~dB}$ ) for a period of $30 \mathrm{~s}$, then the bell was rung $(122 \mathrm{~dB})$, while concomitant behavior was video-recorded. The motor responses were classified using a scale modified from the one originally described by Jobe et al. (1973): no response (NR, in Figure 1, consisting of pause or continuous exploration), wild running (WR, in Figure 1), clonic seizure (CS, in Figure 1), tonic seizure (TS, in Figure 1), respiratory arrest and/or death (RA, in Figure 1). In order to define the intensity of the behavioral response we used the seizure severity score (SSS, in Figure 1) (Musumeci et al., 2000), consisting of a score assigned to each animal depending on its behavioral response $(\mathrm{NR}=0, \mathrm{WR}=1, \mathrm{CS}$ $=2, \mathrm{TS}=3, \mathrm{RA}=4)$. Mice of WT $(n=6$ at P45, $n=4$ at P90) and Fmr1 KO ( $n=9$ at P45, $n=8$ at P90) groups were exposed to a single $60 \mathrm{~s}$ continuous stimulus. As controls, WT $(n=6$ at P45, $n=6$ at P90) and Fmr1 KO mice ( $n=4$ at P45, $n=4$ at P90) were placed in the chamber but the bell was not rung.

\section{IMMUNOHISTOCHEMISTRY AND DENSITOMETRIC ANALYSIS}

Tested WT and Fmrl KO mice, and untested WT and Fmr1 KO mice were decapitated under deep isoflurane anesthesia 14-17 h after the behavioral test. Brains were extracted and cut 


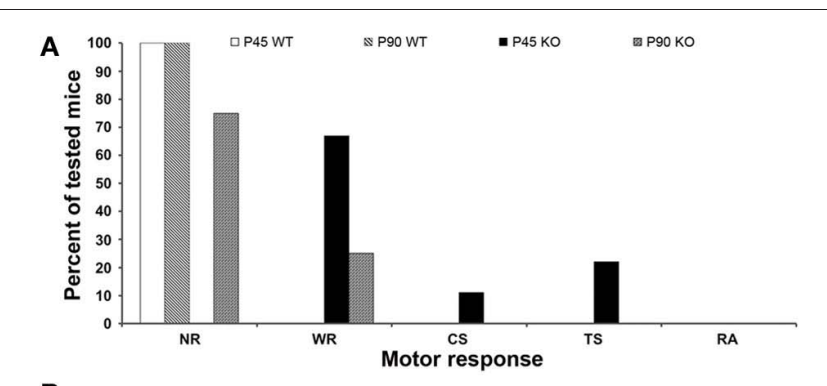

B
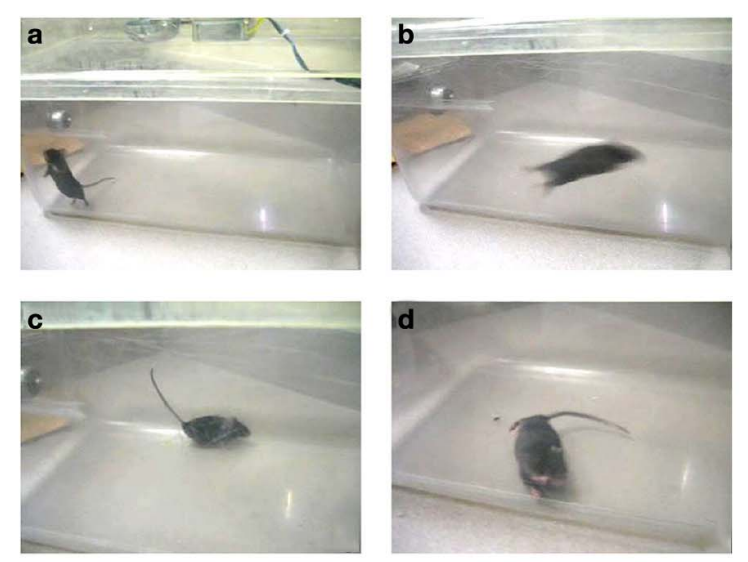

C

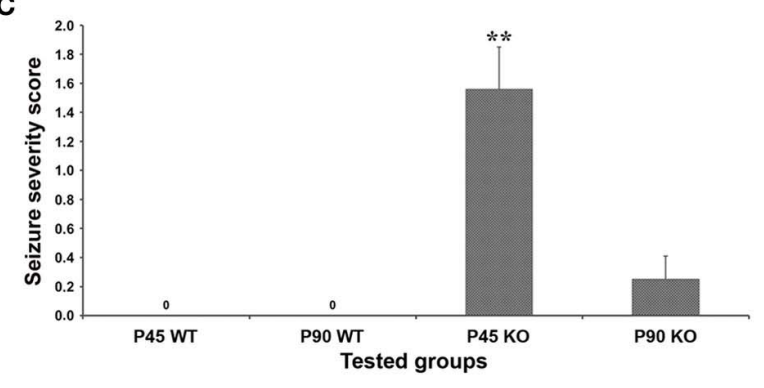

FIGURE 1 | Behavioral response to audiogenic stimuli. (A) Fmr1 KO mice studied at postnatal day (P) 90 showed a less intense motor response to the audiogenic stimuli (6 NR, $2 \mathrm{WR} ; n=8)$ than P45 group (6 WR, $1 \mathrm{CS}$, $2 \mathrm{TS} ; n=9$ ), both higher than WT mice that did not respond behaviorally to the test either at P45 nor at P90. (B) Frames obtained from the video recordings of a P45 WT mouse during exploratory behavior (a), and of P45 Fmr1 KO mice during WR (b), Straub tail (c), TS (d). (C) The seizure severity score (SSS) shows that the intensity of seizing in P45 Fmr1 KO mice is 6 -fold higher than in P90 group, both higher than WT mice (no response). ** $P<0.01$, Kruskal-Wallis test followed by Dunn's test. NR, no response; WR, wild running; CS, clonic seizures; TS, tonic seizures; RA, respiratory arrest.

in $1 \mathrm{~mm}$-thick horizontal sections using a vibratome (VT1000S Leica, Germany); slices were fixed overnight in 4\% formaldehyde, cryoprotected in 15 and 30\% sucrose-buffered solutions, and then stored at $-80^{\circ} \mathrm{C}$. Forty $\mu \mathrm{m}$-thick sections were obtained at the cryostat (Leica, Jung CM 3000, Germany) and processed for immunohistochemistry using a rabbit polyclonal antiFosB/ $\Delta$ FosB (H75) antibody (sc-7203, Santa Cruz Biotechnology, Santa Cruz, CA, USA; dilution 1:250) (Biagini et al., 2005, 2008) or a mouse monoclonal antibody against p-ERK1/2 (Thr202/Tyr204, cat-9106, Cell Signal Technology, Beverly, MA,
USA; dilution 1:1500), according to the avidin-biotin-peroxidase complex technique and using diaminobenzidine as a chromogen (Biagini et al., 2005, 2008). Briefly, sections were treated with $3 \% \mathrm{H}_{2} \mathrm{O}_{2}$ in phosphate buffered saline (PBS) to block endogenous peroxidase and then incubated with the primary antibody for $48 \mathrm{~h}$ at $4^{\circ} \mathrm{C}$. Slices were then incubated with the secondary antibody (dilution 1:200) for $1 \mathrm{~h}$ at room temperature and finally incubated with streptavidin biotinylated horseradish peroxidase complex (dilution 1:300) for $45 \mathrm{~min}$, always at room temperature.

Sections mounted on gelatin-coated slides were analyzed using the image analysis software KS300 (Zeiss-Kontron, Munich, Germany). Background values in stained sections were obtained from areas that did not contain any stained cell (i.e., the angular bundle). Stained profiles were discriminated from background throughout every sampled region (Biagini et al., 1993, 1998, 2005, 2008). Cell profile counts were determined in each field as the number of immunopositive profiles after transformation in D-circles (i.e., the diameter of circles having the same area as measured) by considering a minimum cutoff value of $7 \mu \mathrm{m}$. Cell counts were then divided by the sampled field area and expressed as cell densities. Sampled areas were the hippocampal regions CA1 and CA3, dentate gyrus, presubiculum, subiculum, entorhinal cortex, perirhinal cortex, lateral amygdala, primary auditory cortex, and medial geniculate body.

\section{IMMUNOFLUORESCENCE}

Double-immunostaining experiments were performed on free floating sections washed in PBS at room temperature and permeabilized for $1 \mathrm{~h}$ in PBS containing $0.1 \%$ Triton X-100 and $1 \%$ bovine serum albumin. For double immunolabeling, sections were incubated overnight in a mixture of the mouse monoclonal anti-p-ERK1/2 (1:500) and the rabbit polyclonal anti-FosB/ $\Delta$ FosB antibody (1:250). Further co-labeling experiments were designed using the mouse monoclonal anti-p-ERK (1:500) and, respectively, a rabbit polyclonal antibody against parvalbumin (no. 235, Swant, Bellinzona, CH; diluted at 1:2000), neuropeptide Y (no. IHC 7180, Peninsula, San Carlos, CA, USA; diluted at 1:800), and somatostatin (no. 20089, Immunostar, Hudson, WI, USA; diluted at 1:1000). After washing, sections were incubated for $90 \mathrm{~min}$ at room temperature in a 1:200 dilution of goat anti-mouse AlexaFluor546 ${ }^{\circledR}$ and goat anti-rabbit AlexaFluor488 ${ }^{\circledR}$ (Invitrogen, Carlsbad, California). Sections were counterstained with 4',6 diamidino-2-phenylindole (DAPI, Vector Laboratories, USA) to assess nuclear morphology. Images were visualized using a Leica TCS SP2 confocal microscope, equipped with Argon (488 nm) and Helium/Neon (543 nm).

\section{STATISTICAL ANALYSIS}

Data on behavioral score were analyzed with the Fisher's test. The seizure severity score was analyzed with Kruskal-Wallis nonparametric analysis of variance (ANOVA), followed by post-hoc Dunn's test for multiple comparisons. Cell counts underwent a Three-Way ANOVA, using as factors the genotype (WT or Fmr1 $\mathrm{KO}$ ), the acoustic test (yes or no) and the age (P45 or P90). 
Post-hoc test for multiple comparisons was the Fisher's LeastSignificant-Difference (LSD). Data were analyzed with Sigmaplot 11 (Systat Software, San Jose, CA, USA). Results are shown as mean \pm standard error of the mean $($ SEM), and $P<0.05$ was considered statistically significant.

\section{RESULTS \\ MOTOR RESPONSE ANALYSIS}

Audiogenic stimulus was given once and concomitant animal behavior was observed and scored (Figure 1). The test for AGS did not induce anomalous behaviors in WT mice ( $n=6$ at P45 and $n=4$ at P90; Figure 1A), which continued to explore the novel environment (Figure 1Ba) or, sometimes, paused. In contrast, a motor response was triggered in $\mathrm{P} 45$ Fmr1 KO mice $(n=9), 6$ of which developed wild running episodes (Figure 1Bb) and often presented with the Straub tail (Figure 1Bc); one progressed from wild running to clonic seizures, and 2 further progressed to tonic seizures (Figure 1Bd). In P90 Fmr1 $\mathrm{KO}$ mice $(n=8)$ the response was less marked than in P45 mice: only 2 out of 8 developed wild running episodes (Figure 1A). All mice resumed normal behavior before the acoustic stimulation was over, and death due to respiratory arrest was never observed neither in P45 nor in P90 group. Motor response rate was $100 \%$ in P45 Fmr1 KO group (9 out of 9), 25\% in P90 Fmr1 KO mice (2 out of 8) and 0\% (no response) in P45 and P90 WT groups $(P<0.01$, Fisher's test $)$.

Using a scale created for AGS (see Materials and Methods section for details), the seizure severity score was calculated for each group: it was $1.56 \pm 0.29$ in P45 Fmrl KO mice, $0.25 \pm 0.16$ in P90 Fmr1 KO mice, and 0.0 in P45 and P90 WT mice (Figure 1C). The Kruskal-Wallis test revealed a significant difference between seizure severity score at P45 and P90 Fmrl KO mice $(P<0.01)$. These findings confirm that FXS mice are more susceptible to AGS compared to WT mice and that this susceptibility is agedependent, resulting more pronounced in young adult FXS mice than in older subjects (Musumeci et al., 2000, 2007; Yan et al., 2005).

\section{FosB/ $\Delta$ FosB IMMUNOSTAINING}

In order to disclose the neuronal networks mediating AGS, we mapped FosB/ $\triangle$ FosB expression in activated neurons in hippocampal (Sub, CA1, CA3, DG in Figures 2A,B), parahippocampal (preSub, EC in Figures 2A,C) and extrahippocampal regions (LA in Figures $\mathbf{2 A}, \mathbf{C}$ ), including the auditory pathways (MGB, Aul in Figures 3A,B). FosB/ $\triangle$ FosB immunoreactivity was barely detectable in P45 WT mice in control condition

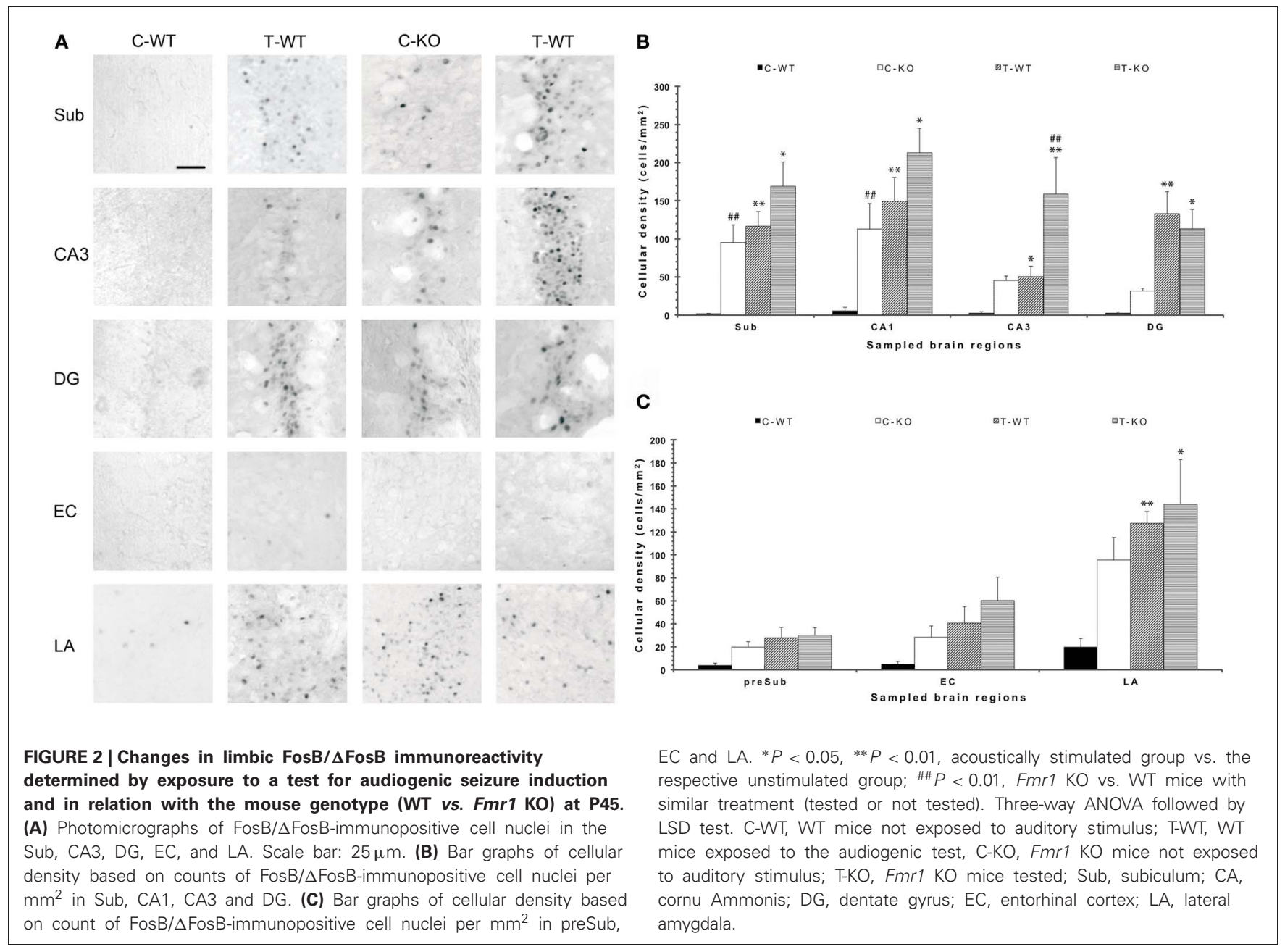


(C-WT; Figure 2A), while it increased after the acoustic test (T-WT) in several brain regions and it reached statistical significance $(P<0.01$, LSD test) in the subiculum, CA1, dentate gyrus, lateral amygdala (Figures $\mathbf{2 B}, \mathbf{C}$ ) and primary acoustic area (Figures 3A,B). A significant $(P<0.05)$ increase was present also in the CA3 hippocampal region (Figures 2A,B). Interestingly, in non-stimulated P45 Fmr1 KO mice, FosB/ $\Delta$ FosB values were significantly higher than in WT mice already in basal conditions ( $\mathrm{C}-\mathrm{KO}$ in Figures 2A,B), particularly in the hippocampus proper $(P<0.01$ for $C A 1)$ and in the subiculum $(P<0.01$; Figure 2B). Following exposure to the test for AGS, FosB $/ \Delta$ FosB immunoreactivity was significantly increased in $\mathrm{P} 45 \mathrm{Fmrl} \mathrm{KO}$ mice (T-KO in Figures $2 \mathrm{~A}-\mathrm{C}$ ) in the hippocampus $(P<0.05$ for CA1 and $P<0.01$ for CA3), subiculum $(P<0.05)$, dentate gyrus $(P<0.05)$, lateral amygdala $(P<0.05)$, medial geniculate body $(P<0.05$, Figure $3 \mathbf{A})$, and primary acoustic cortex $(P<0.05$, Figures 3A,B $)$ compared with unstimulated Fmr1 KO mice, while it was unchanged in the presubiculum and entorhinal cortex (Figures 2A,C). In addition, in the CA3 region the density of immunopositive neurons was significantly $(P<0.01)$ higher in P45 Fmr1 KO mice after the test compared with age-matched WT also exposed to the testing procedure. A significant difference $(P<0.05)$ between the two genotypes, after the auditory test, was also found in the medial geniculate body $(P<0.05$, Figure 3A), but not in other sampled areas (Figures 2B,C, 3A).

Following exposure to the test for AGS of P90 mice, FosB/ $\Delta$ FosB immunoreactivity was not increased in Fmr1 KO mice (T-KO; Table 1) compared with unstimulated P90 Fmr1 KO mice (C-KO; Table 1) in none of the sampled areas, including acoustic regions. In addition, no differences were found in age-matched WT mice (T-WT; Table 1) also exposed to the testing procedure.

The statistical analysis (Three-Way ANOVA) revealed main effects of test exposure in the subiculum $(P<0.05)$, CA3 $(P<0.05)$, dentate gyrus $(P<0.01)$ and amygdala $(P<0.05)$. The different genotype did not affect the level of FosB/ $\Delta$ FosB immunoreactivity in any of the sampled regions, whereas agerelated changes were found in the subiculum $(P<0.05)$ and CA3 $(P<0.05)$. Interestingly, a significant interaction of all the 3 main factors (genotype $\times$ test $\times$ age) was present only in the subiculum $(P<0.05)$. In the hippocampal CA1 and CA3 subfields, as well as in the subiculum, significant $(P<0.01$ for all regions) interactions between test exposure and age, as well as between genotype and age $(P<0.01$ for all regions $)$ were present. Significant interactions between test exposure and age were present in the dentate gyrus $(P<0.01)$ and entorhinal cortex $(P<0.01)$; in the latter we also found a significant interaction between age and

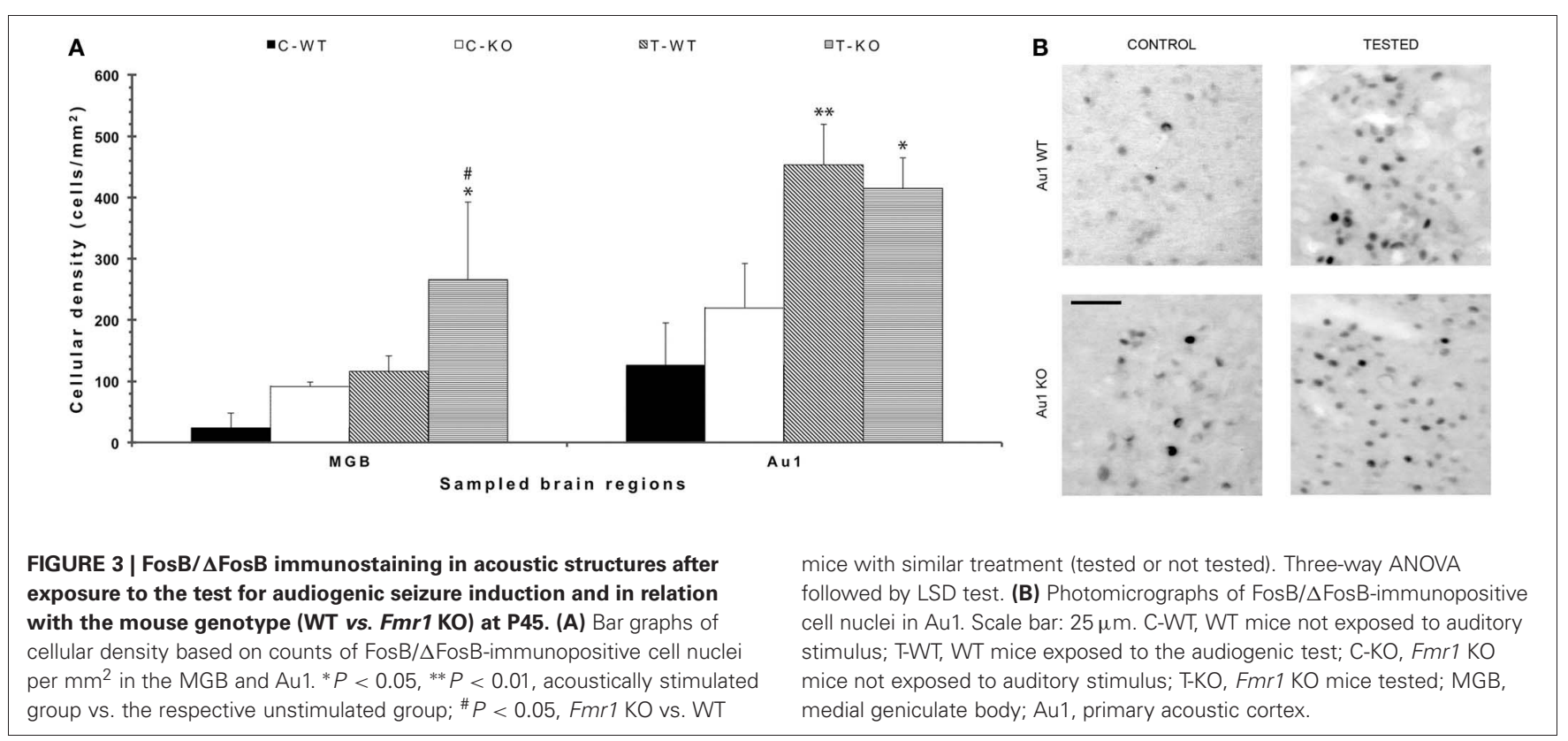

Table 1 | Cellular density based on count of FosB/ $\mathrm{AFosB}$-immunopositive cell nuclei per $\mathrm{mm}^{2}$ in Fmr1 KO and WT mice studied at age P90.

\begin{tabular}{|c|c|c|c|c|c|c|c|c|c|}
\hline & Sub & CA1 & CA3 & DG & preSub & EC & LA & MGB & Au1 \\
\hline C-WT & $117 \pm 20$ & $87 \pm 40$ & $45 \pm 60$ & $89 \pm 40$ & $25 \pm 90$ & $27 \pm 60$ & ND & $13 \pm 20$ & $47 \pm 70$ \\
\hline T-WT & $67 \pm 11$ & $34 \pm 21$ & $29 \pm 20$ & $71 \pm 12$ & $25 \pm 22$ & $12 \pm 50$ & ND & $25 \pm 50$ & $32 \pm 70$ \\
\hline $\mathrm{C}-\mathrm{KO}$ & $76 \pm 42$ & $59 \pm 37$ & $20 \pm 10$ & $35 \pm 16$ & $12 \pm 11$ & $10 \pm 70$ & ND & $36 \pm 16$ & $33 \pm 80$ \\
\hline $\mathrm{T}-\mathrm{KO}$ & $79 \pm 45$ & $42 \pm 20$ & $14 \pm 80$ & $79 \pm 45$ & $14 \pm 80$ & $12 \pm 10$ & ND & $25 \pm 80$ & $78 \pm 13$ \\
\hline
\end{tabular}

No significant differences were found. It was not possible to sample a sufficient number of animals for lateral amygdala (LA).

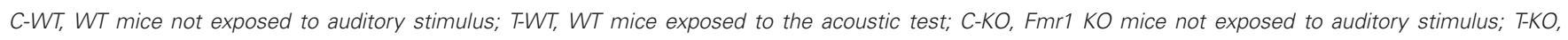

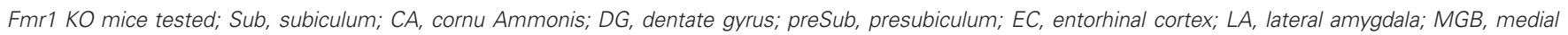
geniculate body; Au1, primary acoustic area; ND, not determined. 
genotype $(P<0.05)$. No significant interactions were found in the amygdala. The analyzed acoustic regions presented with significant effects of test $(P<0.05$ for the medial geniculate body; $P<0.01$ for the primary acoustic region) and age $(P<0.05$ for the medial geniculate body; $P<0.01$ for the primary acoustic region), as well as significant interactions between test exposure and age $(P<0.05$ for the medial geniculate body; $P<0.01$ for the primary acoustic region).

\section{CHANGES OF ERK1/2 ACTIVATION IN RELATION TO SEIZURES AND AGE}

As further marker of neuronal activation, we evaluated p-ERK1/2 immunoreactivity in basal conditions and after the test (Figures 4 and 5). In limbic structures, p-ERK1/2-immunoreactive cells were consistently observed in the subiculum and perirhinal cortex of both strains. Sparse immunopositive cells were also present in other regions in few mice. Thus, we focused on the subiculum and perirhinal cortex to analyze changes in p-ERK1/2-immunoreactive cell counts due to test exposure. In the subiculum, p-ERK1/2-immunoreactive cells were located in the pyramidal cell layer, as in the case of FosB/ $\Delta$ FosBimmunopositive cells (cf. Figure 2A). The Three-way ANOVA revealed a significant $(P<0.05)$ effect of age and a significant $(P<0.01)$ interaction of genotype and test. Notably, a significant $(P<0.01)$ interaction among genotype, age and test was also present. Interestingly, a significant large number of p-ERK1/2immunopositive cells was already detectable in basal conditions

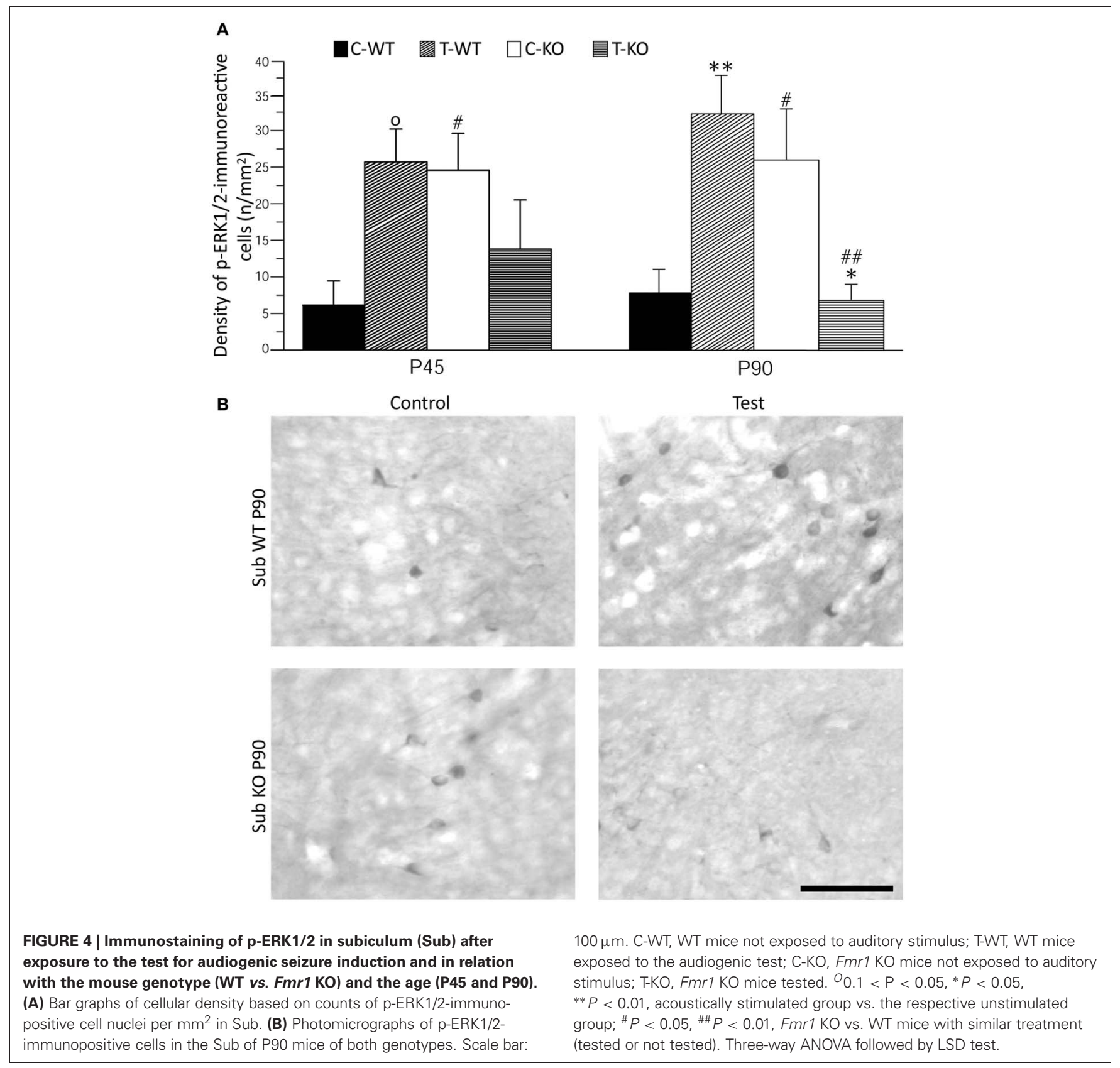


in Fmr1 KO (Figure 4B), both in P45 and P90 groups of age $(P<0.05$, Fisher's LSD test; Figure 4A). After exposure to the AGS test, p-ERK1/2-immunoreactive cells did not change significantly at P45 in both genotypes (but a trend toward increase was present in P45 WT mice; $P=0.06$ vs. basal values), whereas a remarkable decrease $(-75 \%)$ was observed in Fmr1 $\mathrm{KO}$ mice at P90 $(P<0.05$, Figure 4$)$. This change was at variance with the significant $(P<0.01$ vs. basal levels in WT) increase in pERK1/2 levels observed in WT rats exposed to AGS induction. Thus, at P90, after exposure to the AGS test, levels of p-ERK1/2immunopositive cells in Fmrl $\mathrm{KO}$ mice were significantly less than in tested WT $(P<0.01$; Figure 4).

Neuronal immunolabelling with the anti-p-ERK1/2 antibody was consistently observed also in the superficial layers of perirhinal cortex. We analyzed the pattern of p-ERK1/2 immunoreactivity and found them to be similar both in P45 and P90 groups and independent of exposure to the AGS test (Figure 5).

\section{CHARACTERIZATION OF p-ERK1/2-IMMUNOPOSITIVE CELLS}

We investigated whether neurons identified by FosB/ $\Delta$ FosB and p-ERK1/2 antibodies were the same cells or, instead, distinct elements. Experiments of co-labeling with FosB/ $\Delta$ FosB and p-ERK1/2 antibodies in $\mathrm{P} 45$ mice revealed that approximately $50 \%$ of p-ERK1/2-immunopositive cells expressed FosB/ $\Delta$ FosB antigens, whereas the other $50 \%$ was composed by distinct neuronal elements, both in subiculum (Figures 6A-C) and perirhinal cortex (Figures 6D-I), independently of the genotype.

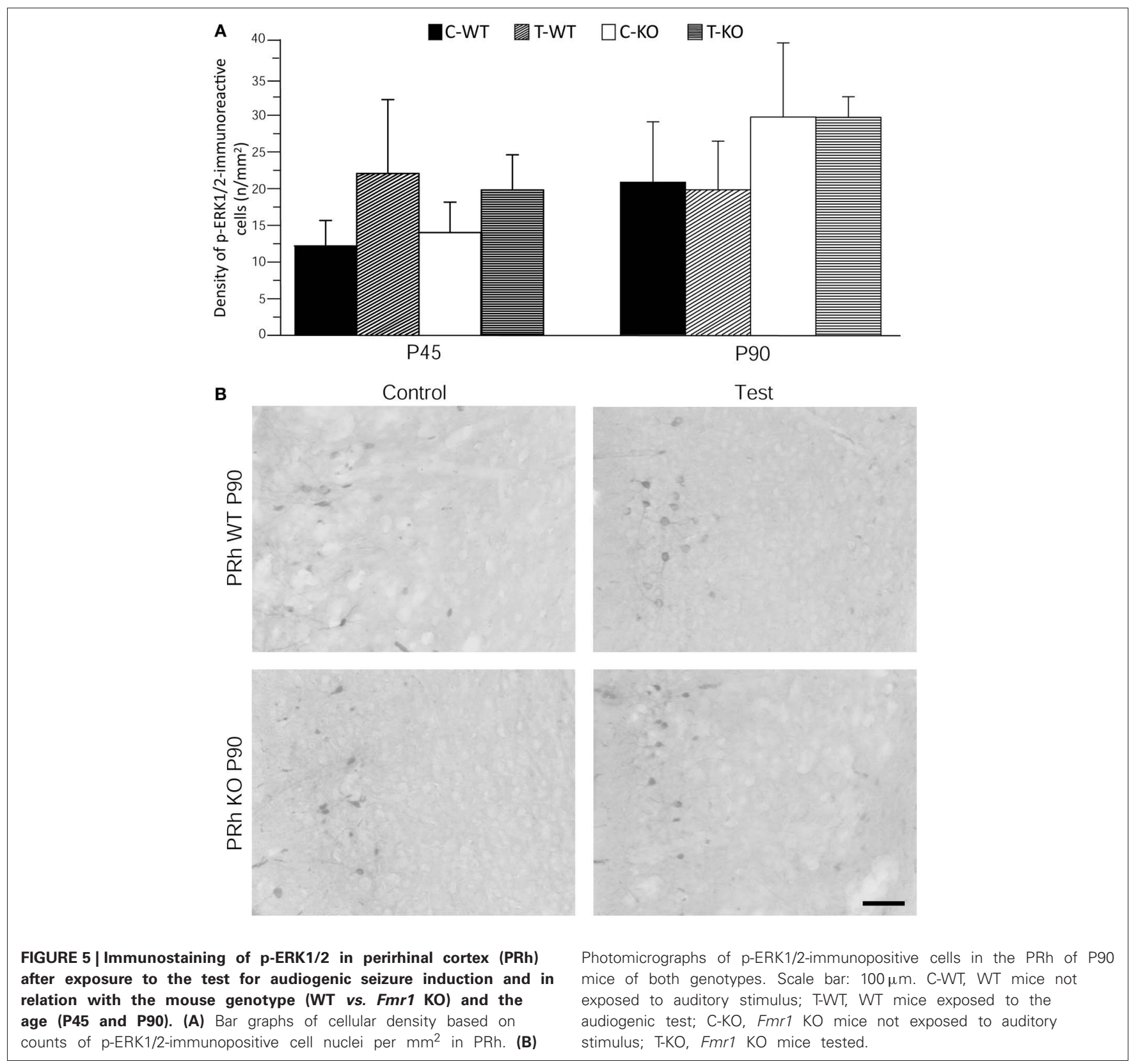



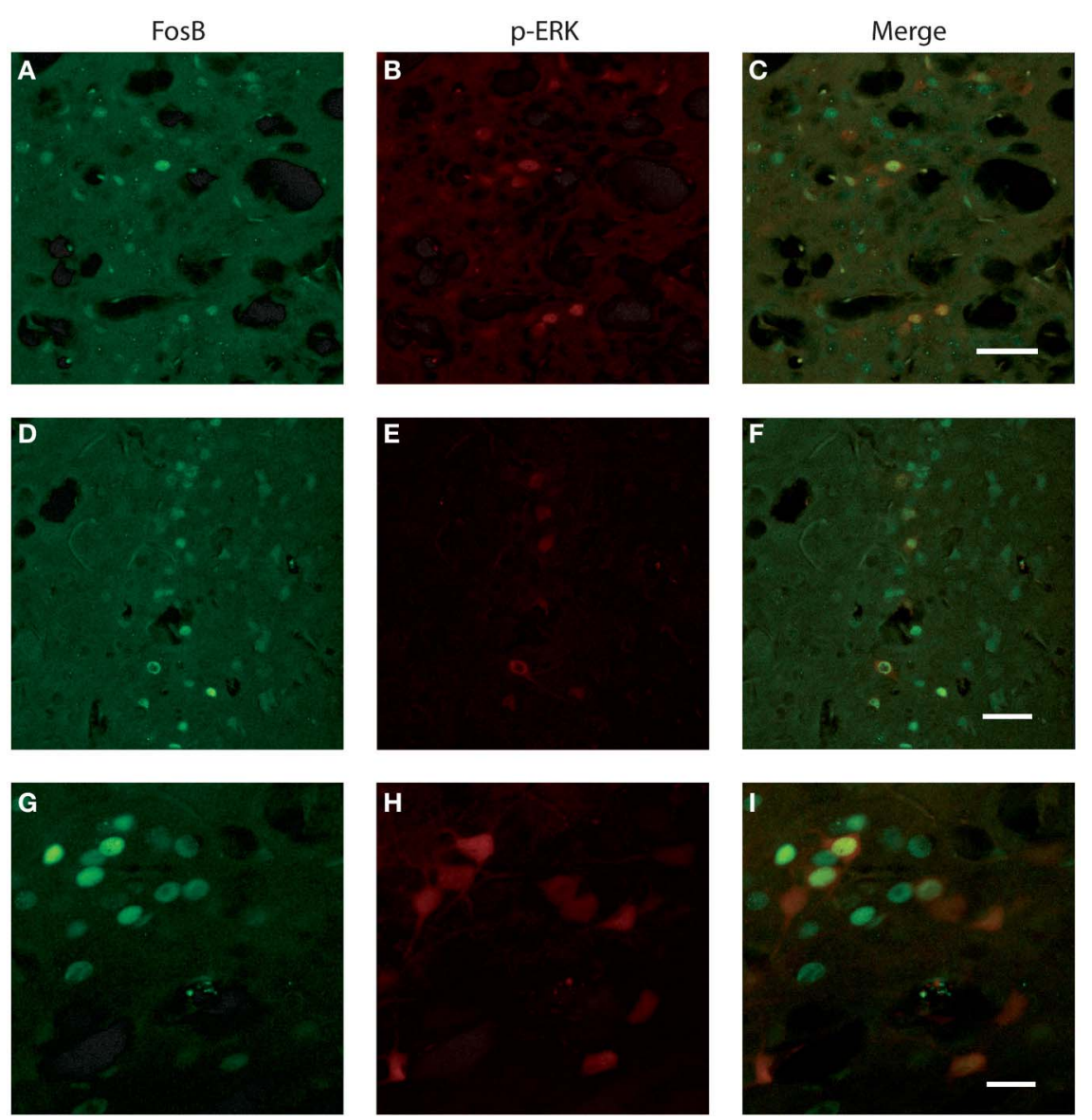

FIGURE 6 | Photomicrographs illustrating double immunofluorescence experiments with antibodies against $p-E R K 1 / 2$ and Fos $B / \Delta F o s B$

in three exampled mice. (A-C) illustrate the co-labeling of subicular neurons in a Fmr1 KO mouse at P45. (D-F) demonstrate the co-labeling found in the perirhinal cortex of a WT mouse at P45. (G-I) Neurons co-labeled in the perirhinal cortex of a WT mouse showed at higher magnification. Scale bars, $50 \mu \mathrm{m}$ for $(\mathbf{A}-\mathbf{F}), 25 \mu \mathrm{m}$ for $(\mathbf{G}-\mathbf{I})$.
We also explored the possibility that p-ERK1/2-immunopositive cells could be interneurons. Experiments of co-labeling with p-ERK1/2 and markers for specific interneuron subclasses were performed in the subiculum (Figure 7) and perirhinal cortex (not shown). These experiments demonstrated that parvalbumin, neuropeptide $\mathrm{Y}$ and somatostatin antibodies, respectively, did not co-localize with cells stained with $\mathrm{p}$-ERK1/2 antibodies (Figure 7).

\section{DISCUSSION}

We investigated the response to the AGS test at two different ages in mice characterized by the Fmrl KO genotype, compared with age-matched control WT mice. As previously reported, FXS patients (Ferri et al., 1994; Miller et al., 1999) and mice (Musumeci et al., 2000) show anomalous reaction to sensory stimuli and our experiments confirm the hyper-reaction of Fmr1 KO mice to loud acoustic stimulus $(\sim 122 \mathrm{~dB})$, given using a doorbell mounted inside the experimental cage. This experimental design gave us the possibility to test either the reaction to sensory stimuli, either the susceptibility to AGS. Reportedly, seizure susceptibility in the FXS is age-dependent: C57BL/6 Fmr1 KO mice showed higher susceptibility between P15 and P47, while it is between P14 and P94 in FVB Fmr1 KO mice (Musumeci et al., 2000, 2007; Yan et al., 2005). This is confirmed in our experiments where P45 C57BL/6 Fmr1 KO mice showed higher susceptibility to AGS than P90 mice. Clinical investigations reported that seizures are found in a small but significant subpopulation of FXS patients during the infancy and usually disappear with maturation (Hagerman and Stafstrom, 2009; Gauthey et al., 2010). The presently reported findings and previous works in the FXS animal model suggest that high homology exists between Fmrl KO mice and the humans with FXS.

We also analyzed the neuronal networks participating in the seizure activity in Fmrl KO mice. In particular, we analyzed FosB/ $\Delta$ FosB expression as an alternative to previous studies based on c-Fos immunoreactivity (Chen and Toth, 2001), another tool being used for many years to track acute changes in neuronal network activity. The analysis of FosB $/ \Delta$ FosB expression presents several advantages, since c-Fos reliability has been questioned in cases of recurrent neuronal synchronization, like the one typical of epileptic animals (Mello et al., 1996). Moreover, the turnover of c-Fos is very rapid when compared to that of other markers, such 


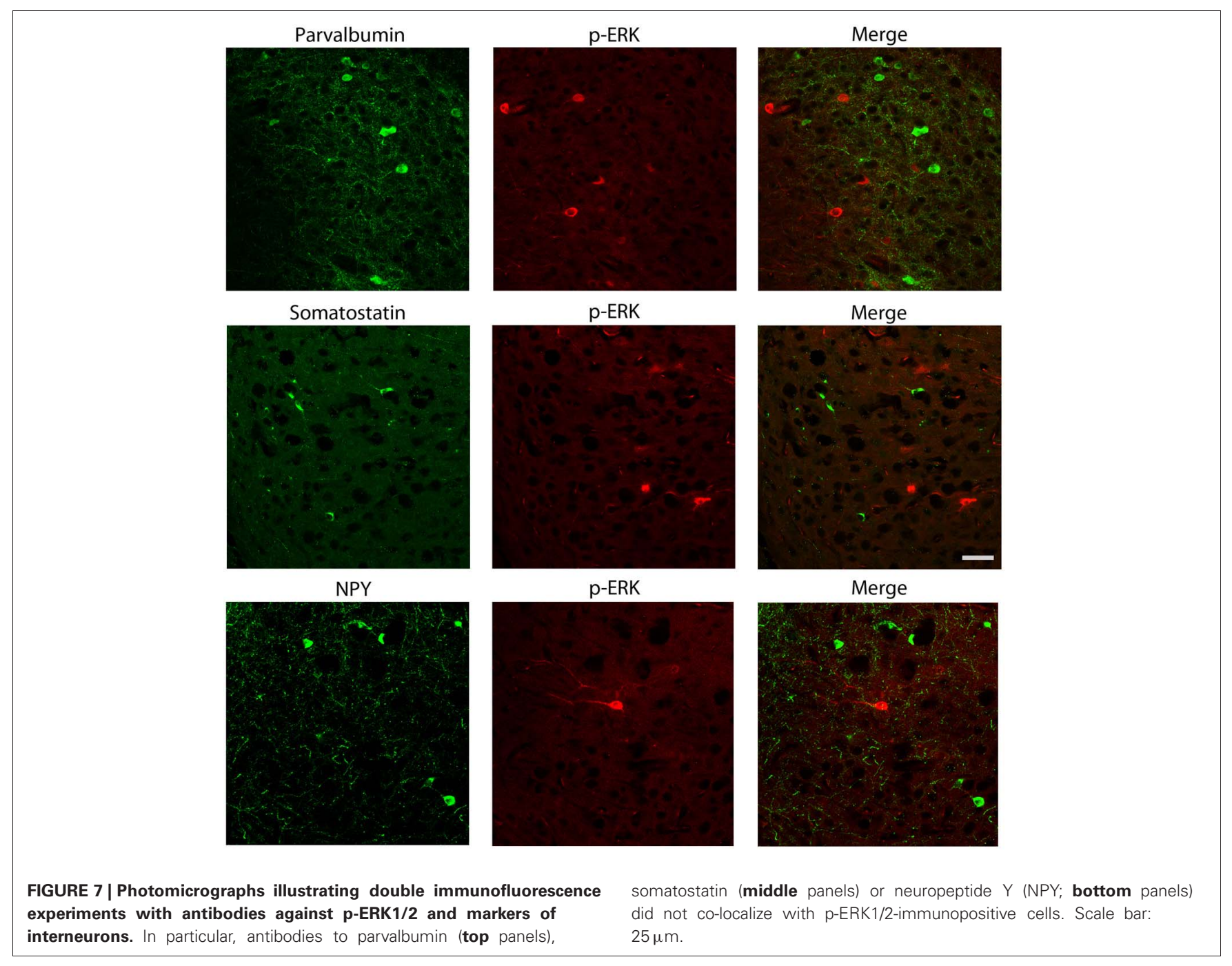

as FosB and $\Delta$ FosB (Madsen et al., 2006), making c-Fos expression extremely short living. In contrast, thanks to their stability, products of the fos $B$ gene family tend to accumulate in repeatedly activated neurons (Chen et al., 1997; Kelz and Nestler, 2000), being the ideal tool available now to investigate network activity in epileptic animals (Chen et al., 1997; Biagini et al., 2005; Madsen et al., 2006). As expected, the acoustic stimulus induced an increased labeling for $\mathrm{Fos} B / \Delta \mathrm{FosB}$ in regions involved in processing auditory information, especially in the medial geniculate body and primary acoustic area, both in WT and Fmr1 KO mice, indicating that acoustic pathways had been activated. These findings are consistent with those by Chen and Toth (2001), demonstrating increased c-Fos expression after acoustic stimulus in specific thalamic regions of the FXS genotype, such as the medial geniculate body, compared to stimulated WT mice. We also observed enhanced FosB/ $\Delta$ FosB immunoreactivity in the medial geniculate body of Fmr1 KO compared with WT stimulated mice. At variance, no differences between the two genotypes were present in FosB $/ \Delta$ FosB expression in the primary acoustic area, a result that is also in agreement with c-Fos immunodetection (Chen and Toth, 2001).
Basal levels of FosB/ $\triangle$ FosB immunoreactivity in the medial geniculate body and primary acoustic area were similar in both genotypes, but a different scenario emerged in the hippocampal formation, in which FosB/ $\Delta$ FosB immunoreactivity was unexpectedly higher in unstimulated P45 Fmrl KO mice compared to age-matched WTs, suggesting that regions notoriously involved in cognitive and emotional physiological functions (Koe et al., 2009; Herry et al., 2010) were hyperactive in our animal model of FXS. These differences were previously unreported in experiments based on antibodies to c-Fos (Chen and Toth, 2001; Li et al., 2002). However, the hippocampus is responsive to acoustic stimuli (Miller and Freedman, 1995) and, as shown in other models, there is a good evidence that some hippocampal regions are strictly related to the formation of memory traces of acoustic information (Huang et al., 2010). The link among acoustic information, seizures and the hippocampus has also been confirmed by evaluating patients affected by TLE (Boutros et al., 2008). In TLE, the hippocampus is consistently involved in epileptic neuronal synchronization (Avoli et al., 2002), thus the enhanced immunopositivity for $\mathrm{FosB} / \triangle \mathrm{FosB}$ found in the CA1 region and in the subiculum of Fmr1 KO mice not exposed to the acoustic 
test could be interpreted as caused by unobserved spontaneous seizures. Alternatively, differences in the response to environmental stimuli or to stress could be taken into account (Miller et al., 1999; Lauterborn, 2004). The CA1 subfield is involved in the termination of the stress response by regulating the neuroendocrine axis that controls corticosterone levels, a function that strictly integrates the effects of stress with memory processing (Joëls et al., 2009). This hippocampal region is especially sensitive to stressful stimuli and can be markedly altered by chronic stress exposure both during development (Biagini et al., 1998) and in the adulthood (Biagini et al., 1993), circumstances that result in the impairment of stress response termination. Even with slightly different results, most likely due to the different type and duration of stress and the different time after stress when tissue was collected, others also demonstrated that changes in $c$-fos gene expression induced by stress are greater in Fmrl KO compared to WT mice (Lauterborn, 2004). In addition, the increase in corticosterone levels is greater in FXS mice compared to WT subjected to the same type of stress (Lauterborn, 2004). In analogy to patients affected by FXS, Fmr1 KO mice presented with a prolonged return to basal corticosterone levels in response to acute stress, which could be related to an altered hippocampal feedback regulation (Markham et al., 2006).

We have evaluated a second marker of neuronal cell activity by characterizing p-ERK1/2-immunopositive cells. ERK is member of the mammalian mitogen-activated protein kinase (MAPK) family of serine/threonine kinases and regulates a variety of physiological and pathophysiological cellular activities (Subramaniam et al., 2004). This is a marker alternative to FosB. ERK1/2 phosphorylation is known to be followed by c-Fos activation. c-Fos phosphorylation is catalyzed by ERK1/2 at Ser374 and, furthermore, the further downstream reaction at Ser362 stabilizes c-Fos for several hours (Okazaki and Sagata, 1995; Murphy et al., 2002). No regulatory effects on FosB are instead reported by ERK1/2 activation (Miller et al., 1998). Accordingly, transactivation by c-Fos is mediated by two $\mathrm{C}$-terminal motifs named HOB1 and HOB2, of which HOB1, absent in FosB (Herdegen and Leah, 1998), can be phosphorylated by ERK1/2. Consistently, our findings on FosB and p-ERK1/2 co-labeling demonstrate only a partial superimposition of these markers, suggesting that activated neurons were indeed responsive to different molecular pathways. It has been proposed a critical role for ERK1/2 in regulating social behaviors, and it has been suggested that it may be an important factor in human psychiatric disorders (Engel et al., 2009; Satoh et al., 2011). Interestingly, Hou et al. (2006) and Price et al. (2007) showed that the basal p-ERK1/2 levels in hippocampal synaptosomes were elevated in Fmr1 KO mice compared to WTs, but p-ERK1/2 could not be increased by stimulating metabotropic glutamate receptor (mGluR) as instead in WT mice. There is, however, some controversy in the literature regarding ERK1/2 activation in Fmr1 KO tissue (Hu et al., 2008; Gross et al., 2010) and given its critical role in synaptic plasticity, as well as in neurodevelopment and regulation of social behaviors, Wang and colleagues (2012) decided to investigate further this question using human brain tissue obtained from FXS patients. For the first time, they demonstrated that ERK1/2 phosphorylation is altered in neocortex and hippocampus of FXS patients, suggesting that there is a chronic activation of the MAPK/ERK kinase (MEK)-ERK1/2 pathway; in addition they confirmed these results in cortical tissue obtained from Fmr1 KO mice (Wang et al., 2012). Similar upregulation of p-ERK1/2 in Fmr1 KO mice was also found by Michalon et al. (2012). In line with these data, we observed a higher level of p-ERK1/2-immunopositive cells in basal conditions, but this difference was specifically found in the subiculum of Fmr1 KO mice. This finding does not exclude that in fresh tissue, studied with different techniques (Michalon et al., 2012; Wang et al., 2012), enhanced ERK1/2 phosphorylation is found in other brain regions, but the subiculum could anyway represent an area of prominent ERK1/2 activation in the FXS model.

Activation of ERK1/2 by phosphorylation is strongly promoted by glutamate release during seizures and by stimulation of glutamate receptors (Jeon et al., 2000; Otani et al., 2003; Merlo et al., 2004; Houser et al., 2008). Interestingly, inhibition of ERK1/2 phosphorylation was shown to decrease in vitro ictogenesis induced by 4-aminopyridine (Merlo et al., 2004). Consistently with these data, a constitutively active form of MEK1 induced ERK1/2 activation and caused spontaneous epileptic seizures when conditionally expressed in the murine brain (Nateri et al., 2007). Recent experiments have cleared the relationship between ERK1/2 phosphorylation and the occurrence of AGS. Using the inhibitor of the MEK-ERK1/2 kinase cascade U0126, three different laboratories were able to block AGS in Fmr1 KO mice (Osterweil et al., 2010; Michalon et al., 2012; Wang et al., 2012). To this regard, we found that p-ERK1/2 immunoreactivity is decreased in the subiculum, but not in perirhinal cortex, of Fmr1 KO mice not manifesting AGS in response to acoustic stimulation. At variance, no significant changes of p-ERK1/2 immunoreactivity were observed in mice presenting with AGS induction. On the other hand, p-ERK1/2 levels were upregulated by the acoustic test in WT mice, in which we did not observe any epileptic response. This discrepancy suggests a differential regulation of ERK1/2 activity in normal and epilepsy-prone animals. Using pilocarpine to induce seizures, Houser and colleagues (2008) actually observed a decrease in p-ERK1/2 levels in naïve mice, whereas ERK1/2 phosphorylation increased immediately before the appearance of recurrent spontaneous seizures in the animals that experienced the pilocarpine-induced status epilepticus. Thus, it is possible that the enhanced phosphorylation of ERK1/2 observed in WT mice in the subiculum represents a molecular fingerprint of the exposure to subthreshold proconvulsive stimuli in presence of a normal genotype, whereas the increase of p-ERK1/2 basal levels found in Fmr1 KO mice could be related to a proconvulsive genotype. In addition, an inefficient p-ERK1/2 dephosphorylation in the subiculum of Fmr1 KO mice appears to be responsible for AGS induction, whereas enhanced phosphatase activity, acquired during maturation, could explain the resilience to proconvulsive stimuli in older Fmr1 KO mice. This overall evidence suggests that abnormally elevated and timely maintained p-ERK1/2 levels in the subiculum are required for AGS induction in Fmr1 KO mice. Notably, the changes we found in p-ERK1/2 levels were age-dependent, suggesting that this mechanism could be involved in the modification of seizure susceptibility during maturation in the FXS. 
Contrary to results obtained in the subiculum, no differences at all were observed in the perirhinal cortex of WT and Fmrl KO mice exposed to the test for AGS induction. This result is consistent with previous findings that showed defective neurotransmission in the subiculum of Fmr1 KO mice (D'Antuono et al., 2003; Curia et al., 2009). In particular, p-ERK1/2 was shown to display regulatory properties on $\gamma$-aminobutyric acid (GABA) type A receptors by decreasing peak currents generated by $\alpha 1 \beta 2 \gamma 2$ combination of subunits, an effect prevented by UO126 treatment (Bell-Horner et al., 2006). This effect on GABA peak current could be particularly important in a background of decreased GABA tonic current, such as that found in Fmrl KO mice (Curia et al., 2009). The subiculum from patients affected by TLE, due to hippocampal sclerosis, was found to generate spontaneous epileptic activity in vitro (Cohen et al., 2002). Consistently, enhanced neuronal excitability was demonstrated in the subiculum of pilocarpinetreated rats, a model of TLE associated with brain damage, in which GABAergic neurons were significantly decreased (De Guzman et al., 2006). Thus, the present findings on markedly

\section{REFERENCES}

Avoli, M., D’Antuono, M., Louvel, J., Köhling, R., Biagini, G., Pumain, R., et al. (2002). Network and pharmacological mechanisms leading to epileptiform synchronization in the limbic system in vitro. Prog. Neurobiol. 68, 167-207.

Bell-Horner, C. L., Dohi, A., Nguyen, Q., Dillon, G. H., and Singh, M. (2006). ERK/MAPK pathway regulates $\mathrm{GABA}_{\mathrm{A}}$ receptors. J. Neurobiol. 66, 1467-1474.

Berry-Kravis, E. (2002). Epilepsy in fragile X syndrome. Dev. Med. Child Neurol. 44, 724-728.

Berry-Kravis, E., Raspa, M., LogginHester, L., Bishop, E., Holiday, D., and Bailey, D. B., et al. (2010). Seizures in Fragile $\mathrm{X}$ syndrome: characteristics and comorbid diagnoses. Am. J. Intellect. Dev. Disabil. 115, 461-472.

Biagini, G., Baldelli, E., Longo, D., Contri, M. B., Guerrini, U., Sironi, L., et al. (2008). Pro-epileptic influence of a vascular lesion affecting entorhinal cortex-CA3 connections after status epilepticus. J. Neuropathol. Exp. Neurol. 67, 687-701.

Biagini, G., D’Arcangelo, G., Baldelli, E., D’Antuono, M., Tancredi, V., and Avoli, M. (2005). Impaired activation of CA3 pyramidal neurons in the epileptic hippocampus. Neuromol. Med. 7, 325-342.

Biagini, G., Pich, E. M., Carani, C., Marrama, P., and Agnati, L. F. (1998). Postnatal maternal separation during the stress hyporesponsive period enhances the adrenocortical response to novelty in adult rats by affecting feedback regulation in the CA1 hippocampal field. Int. J. Dev. Neurosci. 16, 187-197.

Biagini, G., Pich, E. M., Carani, C., Marrama, P., Gustafsson, J. A., Fuxe, K., et al. (1993). Indole-pyruvic acid, a tryptophan ketoanalogue, antagonizes the endocrine but not the behavioral effects of repeated stress in a model of depression. Biol. Psychiatry 33, 712-719.

Boutros, N. N., Mears, R., Pflieger, M. E., Moxon, K. A., Ludowig, E., and Rosburg, T. (2008). Sensory gating in the human hippocampal and rhinal regions: regional differences. Hippocampus 18, 310-342.

Brooks-Kayal, A. (2011). Molecular mechanisms of cognitive and behavioral comorbidities of epilepsy in children. Epilepsia 52(Suppl. 1), 13-20.

Chen, J., Kelz, M., Hope, B. T., Nakabeppu, Y., and Nestler, E. J. (1997). Chronic Fos-related antigens: stable variants of FosB induced in brain by chronic treatments. J. Neurosci. 17, 4933-4941.

Chen, L., and Toth, M. (2001). Fragile X mice develop sensory hyper reactivity to auditory stimuli. Neuroscience 103, 1043-1050.

Cifelli, P., and Grace, A. A. (2012). Pilocarpine-induced temporal lobe epilepsy in the rat is associated with increased dopamine neuron activity. Int. J. Neuropsychopharmacol. 15, 957-964.

Cohen, I., Navarro, V., Clemenceau, S., Baulac, M., and Miles, R. (2002).

enhanced FosB $/ \Delta$ FosB levels and $p$-ERK1/2 expression in the subiculum of Fmrl KO mice further support the view of a critical role of this limbic region in controlling the spread of seizure activity in neuronal networks also in models of genetic epilepsy.

\section{ACKNOWLEDGMENTS}

This investigation has been supported by the Italian Ministry for Education, University and Research (PRIN2007, grant 2007CX2R77_002 to Giuseppe Biagini; "Rientro Cervelli” project 17DZE8RZEA to Giulia Curia), the University of Modena and Reggio Emilia (UNIMORE), the Fondazione Cassa di Risparmio di Modena (FCRM to Giuseppe Biagini), the Pierfranco and Luisa Mariani Foundation (R-12-94 to Giulia Curia and Giuseppe Biagini). We acknowledge the generous collaboration to this project of Dr. Massimo Avoli, who allowed Dr. Fabio Gualtieri to perform the AGS test on colonies hosted at the Animal Facility of the Montreal Neurological Institute during his sabbatical leave, granted by the PhD School in Clinical and Experimental Medicine of UNIMORE.

On the origin of interictal activity in human temporal lobe epilepsy in vitro. Science 298, 1350-1351.

Curia, G., Papouin, T., Seguela, P., and Avoli, M. (2009). Downregulation of tonic GABAergic inhibition in a mouse model of Fragile $\mathrm{X}$ syndrome. Cereb. Cortex 19, 1515-1520.

D’Ambrosio, R., Hakimian, S., Stewart, T., Verley, D. R., Fender, J. S., Eastman, C. L., et al. (2009). Functional definition of seizure provides new insight into posttraumatic epileptogenesis. Brain 132, 2805-2821.

D'Antuono, M., Merlo, D., and Avoli, M. (2003). Involvement of cholinergic and GABAergic systems in the Fragile $\mathrm{X}$ knockout mice. Neuroscience 119, 9-13.

De Guzman, P., Inaba, Y., Biagini, G., Baldelli, E., Mollinari, C., Merlo, D., et al. (2006). Subiculum network excitability is increased in a rodent model of temporal lobe epilepsy. Hippocampus 16, 843-860.

De Rubeis, S., and Bagni, C. (2010). Fragile X mental retardation protein control of neuronal mRNA metabolism: insights into mRNA stability. Mol. Cell. Neurosci. 43, 43-50.

Dombrowski, C., Lévesque, S., Morel, M. L., Rouillard, P., Morgan, K., and Rousseau, F. (2002). Premutation and intermediate-size FMR1 alleles in 10572 males from the general population: loss of an AGG interruption is a late event in the generation of fragile $\mathrm{X}$ syndrome alleles. Hum. Mol. Genet. 11, 371-378.
Eisermann, M. M., De La Raillère, A., Dellatolas, G., Tozzi, E., Nabbout, R., Dulac, O., et al. (2003). Infantile spasms in Down syndrome-effects of delayed anticonvulsive treatment. Epilepsy Res. 55, 21-27.

Engel, S. R., Creson, T. K., Hao, Y., Shen, Y., Maeng, S., Nekrasova, T., et al. (2009). The extracellular signal-regulated kinase pathway contributes to the control of behavioral excitement. Mol. Psychiatry 14, 448-461.

Ferri, R., Musumeci, S. A., Elia, M., Del Gracco, S., Scuderi, C., and Bergonzi, P. (1994). BIT-mapped somatosensory evoked potentials in the fragile $\mathrm{X}$ syndrome. Neurophysiol. Clin. 24, 413-426.

Garcia-Nonell, C., Ratera, E. R., Harris, S., Hessl, D., Ono, M. Y., Tartaglia, N., et al. (2008). Secondary medical diagnosis in fragile $\mathrm{X}$ syndrome with and without autism spectrum disorder. Am. J. Med. Genet A 146A, 1911-1916.

Gauthey, M., Poloni, C., Ramelli, G. P., Roulet-Perez, E., and Korff, C. M. (2010). Status epilepticus in fragile X syndrome. Epilepsia 51, 2470-2473.

Gross, C., Nakamoto, M., Yao, X., Chan, C. B., Yim, S. Y., Ye, K., et al. (2010). Excess phosphoinositide 3kinase subunit synthesis and activity as a novel therapeutic target in fragile X syndrome. J. Neurosci. 30, 10624-10638.

Hagerman, P. J., and Stafstrom, C. E. (2009). Origins of epilepsy in fragile X syndrome. Epilepsy Curr. 4, 108-112. 
Hagerman, R. J. (1996). "Physical and behavioral phenotype," in Fragile $X$ Syndrome: Diagnosis, Treatment, and Research, eds R. J. Hagerman and P. J. Hagerman (Baltimore, MD: The John Hopkins University Press), 3-87.

Henry, K. R. (1967). Audiogenic seizure susceptibility induced in C57B1/6J mice by prior auditory exposure. Science 158, 938-940.

Herdegen, T., and Leah, J. D. (1998). Inducible and constitutive transcription factors in the mammalian nervous system: control of gene expression by Jun, Fos and Krox, and CREB/ATF proteins. Brain Res. Rev. 28, 370-490.

Herry, C., Ferraguti, F., Singewald, N., Letzkus, J. J., Ehrlich, I., and Lüthi, A. (2010). Neuronal circuits of fear extinction. Eur. J. Neurosci. 31, 599-612.

Hou, L., Antion, M. D., Hu, D., Spencer, C. M., Paylor, R., and Klann, E. (2006). Dynamic translational and proteasomal regulation of fragile $\mathrm{X}$ mental retardation protein controls mGluR-dependent long-term depression. Neuron 51, 441-454.

Houser, C. R., Huang, C. S., and Peng, Z. (2008). Dynamic seizure-related changes in extracellular signalregulated kinase activation in a mouse model of temporal lobe epilepsy. Neuroscience 156, 222-237.

Hu, H., Qin, Y., Bochorishvili, G., Zhu, Y., van Aelst, L., and Zhu, J. J. (2008). Ras signaling mechanisms underlying impaired GluR1dependent plasticity associated with fragile X syndrome. J. Neurosci. 28, 7847-7862.

Huang, C. H., Chiang, Y. W., Liang, K. C., Thompson, R. F., and Liu, I. Y. (2010). Extra-cellular signalregulated kinase 1/2 (ERK1/2) activated in the hippocampal CA1 neurons is critical for retrieval of auditory trace fear memory. Brain Res. 1326, 143-151.

Incorpora, G., Sorge, G., Sorge, A., and Pavone, L. (2002). Epilepsy in fragile X syndrome. Brain Dev. 24, 766-769.

Jeon, S. H., Kim, Y. S., Bae, C. D., and Park, J. B. (2000). Activation of JNK and p38 in rat hippocampus after kainic acid induced seizure. Exp. Mol. Med. 32, 227-230.

Jobe, P. C., Picchioni, A. L., and Chin, L. (1973). Role of brain norepinephrine in audiogenic seizure in the rat. J. Pharmacol. Exp. Ther. 184, $1-10$.

Joëls, M., Krugers, H. J., Lucassen, P. J., and Karst, H. (2009). Corticosteroid effects on cellular physiology of limbic cells. Brain Res. 1293, 91-100.
Kelz, M. B., and Nestler, E. J. (2000). $\triangle$ FosB: a molecular switch underlying long-term neural plasticity. Curr. Opin. Neurol. 13, 715-720.

Koe, A. S., Jones, N. C., and Salzberg, M. R. (2009). Early life stress as an influence on limbic epilepsy: an hypothesis whose time has come? Front. Behav. Neurosci. 3:24. doi: 10.3389/neuro.08.024.2009

Lauterborn, J. C. (2004). Stress induced changes in cortical and hypothalamic $c$-fos expression are altered in fragile X mutant mice. Mol. Brain Res. 131, 101-109.

Li, J., Pelletier, M. R., Perez Velazquez, J. L., and Carlen, P. L. (2002). Reduced cortical synaptic plasticity and GluR1 expression associated with fragile $\mathrm{X}$ mental retardation protein deficiency. Mol. Cell. Neurosci. 19, 138-151.

Madsen, T. M., Bolwig, T. G., and Mikkelsen, J. D. (2006). Differential regulation of c-Fos and FosB in the rat brain after amygdala kindling. Cell. Mol. Neurobiol. 26, 87-100.

Markham, J. A., Beckel-Mitchener, A. C., Estrada, C. M., and Greenough, W. T. (2006). Corticosterone response to acute stress in a mouse model of Fragile X syndrome. Psychoneuroendocrinology 31, 781-785.

Mello, L. E., Kohman, C. M., Tan, A. M., Cavalheiro, E. A., and Finch, D. M. (1996). Lack of Foslike immunoreactivity after spontaneous seizures or re-induction of status epilepticus by pilocarpine in rats. Neurosci. Lett. 208, 133-137.

Merlo, D., Cifelli, P., Cicconi, S., Tancredi, V., and Avoli, M. (2004). 4-Aminopyridine-induced epileptogenesis depends on activation of mitogen-activated protein kinase ERK. J. Neurochem. 89, 654-659.

Michalon, A., Sidorov, M., Ballard, T. M., Ozmen, L., Spooren, W., Wettstein, J. G., et al. (2012). Chronic pharmacological mGlu5 inhibition corrects fragile $\mathrm{X}$ in adult mice. Neuron 74, 49-56.

Miller, C., Zhang, M., He, Y., Zhao, J., Pelletier, J. P., Martel-Pelletier, J., et al. (1998). Transcriptional induction of cyclooxygenase-2 gene by okadaic acid inhibition of phosphatase activity in human chondrocytes: co-stimulation of AP-1 and CRE nuclear binding proteins. J. Cell Biochem. 69, 392-413.

Miller, C. L., and Freedman, R. (1995). The activity of hippocampal interneurons and pyramidal cells during the response of the hippocampus to repeated auditory stimuli. Neuroscience 69, 371-381.
Miller, L. J., McIntosh, D. N., McGrath, J., Shyu, V., Lampe, M., Taylor, A. K., et al. (1999). Electrodermal responses to sensory stimuli in individuals with Fragile X syndrome: a preliminary report. Am. J. Med. Genet. 83, 268-279.

Murphy, L. O., Smith, S., Chen, R. H., Fingar, D. C., and Blenis, J. (2002). Molecular interpretation of ERK signal duration by immediate early gene products. Nat. Cell Biol. 4, 556-564.

Musumeci, S. A., Bosco, P., Calabrese, G., Bakker, K., De Sarro, G. B., Elia, M., et al. (2000). Audiogenic seizures susceptibility in transgenic mice with Fragile $\mathrm{X}$ syndrome. Epilepsia 41, 19-23.

Musumeci, S. A., Calabrese, G., Bonaccorso, C. M., D'Antoni, S., Brouwer, J. R., Bakker, C. E., et al. (2007). Audiogenic seizure susceptibility is reduced in fragile $\mathrm{X}$ knockout mice after introduction of FMR1 trans-genes. Exp. Neurol. 203, 233-240.

Musumeci, S. A., Colognola, R. M., Ferri, R., Gigli, G. L., Petrella, M. A., Sanfilippo, S., et al. (1988). Fragile$\mathrm{X}$ syndrome: a particular epileptogenic EEG pattern. Epilepsia 29, 41-47.

Musumeci, S. A., Elia, M., Ferri, R., Scuderi, C., and Del Gracco, S. (1994). Evoked spikes and giant somatosensory evoked potentials in a patient with fragile-X syndrome. Ital. J. Neurosci. 15, 365-368.

Musumeci, S. A., Ferri, R., Elia, M. Colognola, R. M., Bergonzi, P., and Tassinari, C. A. (1991). Epilepsy and fragile $\mathrm{X}$ syndrome: a followup study. Am. J. Med. Genet. 38, 511-513.

Musumeci, S. A., Hagerman, R. J., Ferri, R., Bosco, P., Dalla Bernardina, B., Tassinari, C. A., et al. (1999). Epilepsy and EEG findings in males with fragile X syndrome. Epilepsia 40, 1092-1099.

Nateri, A. S., Raivich, G., Gebhardt, C., Da Costa, C., Naumann, H., Vreugdenhil, M., et al. (2007). ERK activation causes epilepsy by stimulating NMDA receptor activity. ЕМВО J. 26, 4891-4901.

Okazaki, K., and Sagata, N. (1995). The Mos/MAP kinase pathway stabilizes c-Fos by phosphorylation and augments its transforming activity in NIH $3 \mathrm{~T} 3$ cells. EMBO J. 14 5048-5059.

Osterweil, E. K., Krueger, D. D., Reinhold, K., and Bear, M. F. (2010). Hypersensitivity to mGluR5 and ERK1/2 leads to excessive protein synthesis in the hippocampus of a mouse model of fragile X syndrome. J. Neurosci. 30, 15616-15627.

Otani, N., Nawashiro, H., Yano, A., Katoh, H., Ohnuki, A., Miyazawa, T., et al. (2003). Characteristic phosphorylation of the extracellular signal-regulated kinase pathway after kainate-induced seizures in the rat hippocampus. Acta Neurochir. Suppl. 86, 571-573.

Price, T. J., Rashid, M. H., Millecamps, M., Sanoja, R., Entrena, J. M., and Cervero, F. (2007). Decreased nociceptive sensitization in mice lacking the fragile $\mathrm{X}$ mental retardation protein: role of mGluR $1 / 5$ and mTOR J. Neurosci. 27, 13958-13967.

Rousseau, F., Rouillard, P., Morel, M. L., Khandjian, E. W., and Morgan, K. (1995). Prevalence of carriers of premutation-size alleles of the FMRI gene-and implications for the population genetics of the Fragile X syndrome. Am. J. Hum. Genet. 57, 1006-1018.

Sabaratnam, M., Vroegop, P. G., and Gangadharan, S. K. (2001). Epilepsy and EEG findings in 18 males with fragile X syndrome. Seizure 10, 60-63.

Satoh, Y., Endo, S., Nakata, T. Kobayashi, Y., Yamada, K., Ikeda, T., et al. (2011). ERK2 contributes to the control of social behaviors in mice. J. Neurosci. 31, 11953-11967.

Singh, R., Sutherland, G., and Manson, J. (1999). Partial seizures with focal epileptogenic electroencephalographic patterns in three related female patients with fragile $\mathrm{X}$ syndrome. J. Child Neurol. 14, 108-112.

Subramaniam, S., Zirrgiebel, U., von Bohlen Und Halbach, O., Strelau, J., Laliberté, C., Kaplan, D. R., et al. (2004). ERK activation promotes neuronal degeneration predominantly through plasma membrane damage and independently of caspase-3. J. Cell Biol. 165, 357-369.

The Dutch-Belgian Fragile X Consorthium. (1994). Fmrl knockout mice: a model to study fragile X mental retardation. Cell 78, 23-33.

Wang, X., Snape, M., Klann, E., Stone, J. G., Singh, A., Petersen, R. B., et al. (2012). Activation of the extracellular signal-regulated kinase pathway contributes to the behavioral deficit of fragile X-syndrome. J. Neurochem. 121, 672-679.

Yan, Q. J., Rammal, M., Tranfaglia, M., and Bauchwitz, R. P. (2005). Suppression of two major Fragile $\mathrm{X}$ Syndrome mouse model phenotypes by the mGluR5 antagonist MPEP. Neuropharmacology 49, 1053-1066. 
Zalfa, F., Achsel, T., and Bagni, C. (2006). mRNPs, polysomes or granules: FMRP in neuronal protein synthesis. Curr. Opin. Neurobiol. 16, 265-269.

Conflict of Interest Statement: The authors declare that the research was conducted in the absence of any commercial or financial relationships that could be construed as a potential conflict of interest.

Received: 08 February 2013; paper pending published: 08 March 2013; accepted: 03 April 2013; published online: 25 April 2013.
Citation: Curia G, Gualtieri F, Bartolomeo R, Vezzali R and Biagini $G$ (2013) Resilience to audiogenic seizures is associated with p-ERK1/2 dephosphorylation in the subiculum of Fmr knockout mice. Front. Cell. Neurosci. 7:46. doi: 10.3389/fncel.2013.00046 Copyright () 2013 Curia, Gualtieri, Bartolomeo, Vezzali and Biagini.
This is an open-access article distributed under the terms of the Creative Commons Attribution License, which permits use, distribution and reproduction in other forums, provided the original authors and source are credited and subject to any copyright notices concerning any third-party graphics etc. 